\title{
Evaluation of Some Introduced and Local Radish Varieties under Egyptian Conditions
}

\author{
A. M. A. Hamouda*, E. M. E. A. Khalil ${ }^{* *}$ and Omneya F. \\ Abu El-Leel* \\ * Medicinal and Aromatic Plant Research Department and \\ *** Breeding Vegetable Crops \& Medicinal and Aromatic Plants \\ Research Department, Horticulture Research Institute, \\ Agricultural Resrach Centre, Cairo, Egypt.
}

\begin{abstract}
7 HE PRESENT work was conducted at the experimental farm of the Vegetables Research Farm in Kaha, Governorate, Egypt in the two successive seasons of 2010/2011 and 2011/2012 to study the differences in growth and root characters, fixed oil production as well as its chemical compositions and molecular genetic identifications between some introduced and local radish varieties to be used in breeding programs. Seeds of radish local varieties, Inbred line selected, Ballady, Round-Red and Chinese radish varieties, Lingyu, Lingcui, Hongxiu, Fongguang and Guoguang were sown in a well prepared soil on October $15^{\text {th }}$ in the two seasons. The results revealed that, Fongguang variety overpass of root length, root weight, seed yield/plant $(\mathrm{g})$ and fixed oil yield $(\mathrm{ml}) /$ plant, meanwhile, Lingyu variety overpass of root diameter, seed yield/plant $(\mathrm{g})$ and fixed oil yield (ml)/plant. Regarding the fixed oil constituents; the best variety which gave the highest value of palmitic acid was Inbred line selected variety while, oleic acid from Lingyu variety, the lowest value of Erucic acid $(29.1 \%)$ was obtained from Hongxiu variety. Genetic and chemical differences of eight individuals of Raphanus sativus L. were studied to determine whether molecular characters could be used as taxonomical markers and to examine the correlation between them. Only five primers simplified all DNA templates among 15 primers. Primers generated a total of 64 DNA fragments, (64\%) were polymorphic. The number of polymorphic bands scored per primer ranged from 6 (primers OP-D05 and OP-P15) to 13 (primer OP-K12). The largest number of RAPD-PCR markers was scored for Lingyu and Fongguang genotypes (12 markers), while the lowest (4 markers) was scored for Hongxiu genotype. In the meantime, the largest number of RAPD-PCR variety-specific markers was generated by primer OP-K12 (5 markers), while the lowest number of RAPD-PCR specific markers (1marker) was generated by primer OP-D05.
\end{abstract}

Radish, Raphanus sativus L. is an edible root vegetable of the Brassicaceae family and one of the staple vegetable crops in Asia, especially in China, Japan, and Korea. Cultivated radish has been classified into many varieties according to the morphology of its edible root and different usages, such as $R$. sativus var. sativus (European small radish), var. Hortensis Becker (East Asian big long radish), var. Niger Kerner (black 
radish), var. chinensis Gallizioli (Chinese oil radish) and var. caudatus Hooler and Anderson (tail-podded radish) Lu et al. (2008).

Radish (Raphanus sativus L.) is an important crop that is cultivated all over the world. The root axis of radish is composed of two anatomically distinct parts. The upper part originates from the hypocotyls and lateral roots are not present on this part. The lower part consists of true root tissue, and lateral roots are developed in this part. These two parts of the radish root can thicken and form succulent tissue, which is used as a vegetable Tsuro et al. (2008).

Radish, the well known part of your salad, is a root crop, pungent or sweet in taste with a lot of juice. Radishes can be white, red, purple or black, long cylindrical or round in shape. They are eaten fresh, cooked or pickled. The fixed oil obtained from the seeds of radish is also used.

Oilseed radish is used as a cover crop, or a crop grown specifically to maintain cropland soil quality, fertility and productivity. Typically, cover crops are not harvested and are terminated on the surface or incorporated into soil before they mature (Magdoff and Van Es, 2009). Cover crop species generally limit soil erosion because they provide cover to the soil when the soil would normally be fallow.

Oilseed radish develops a unique taproot that reaches depths of six feet. The upper 12-20 inches of the taproot thicken and can grow to 2 inches in diameter (Weil et al., 2006). This deep rooting growth habit is capable of treating multiple resource concerns on cropland, such as: the open pollination habit helped the species to accumulate abundant variations. It was reported that even the flora morphology exhibited great variations among the radish accessions Kobayashi et al. (2006). Those variations offered abundant genetic resources for radish genetic enhancement.

Palmitic acid (C16:0), according to the World Health Organization evidence, it is "convincing" that consumption of palmitic acid increases risk of developing cardiovascular diseases, placing it in the same evidence category as trans fatty acids. Retinyl palmitate is an antioxidant and a source of vitamin A added to low fat milk to replace the vitamin content lost through the removal of milk fat. Palmitateis attached to the alcohol form of vitamin A, retinol, to make vitamin A stable in milk. Rats fed a diet of $20 \%$ palmitic acid and $80 \%$ carbohydrate for extended periods showed alterations in central nervous system control of insulin secretion, and suppression of the body's natural appetite-suppressing signals from leptin and insulin (the key hormones involved in weight regulation). Palmitoleic acid (C16:1) the significance of palmitoleic acid in U.S. military nutrition research is also mentioned in a 2011 study. This preliminary research cites palmitoleic acid as a possible protective factor related to mental health and suicide and states that service members with higher levels of palmitoleic acid may have lower risk of suicide. Oleic acid (C18:1) Oleic acid is a common monounsaturated fat in human diet. Monounsaturated fat consumption has been 
associated with decreased low-density lipoprotein (LDL) cholesterol and possibly increased high-density lipoprotein (HDL) cholesterol. However, its ability to raise HDL is still debated.Oleic acid may hinder the progression of adreno leuko dystrophy (ALD), a fatal disease that affects the brain and adrenal glands.Oleic acid may be responsible for the hypotensive (blood pressure reducing) effects of olive oil. Adverse effects also have been documented, however, since both oleic and monounsaturated fatty acid levels in the membranes of red blood cells have been associated with increased risk of breast cancer, although the consumption of oleate in olive oil has been associated with a decreased risk of breast cancer. Erucic acid (C22:1) The name erucic means: of or pertaining to eruca; which is a genus of flowering plants in the family Brassicaceae. It is also the Latin for colewort, which today is better known as kale. Erucic acid is produced naturally (together with other fatty acids) across a great range of green plants, but especially so in members of the brassica family. For industrial purposes, a LowErucic. Acid Rapeseed (LEAR) has been developed, which contains fats derived from oleic acid instead of erucic acid.

\section{Genetic of radish}

As a result, appraisal on the genetic diversity of radish will be greatly conducive to the utilization and improvement of radish germplasm. In previous studies, radish germplasm resources were identified with different methods such as morphological traits George and Evans (1981) and isozyme markers Ellstrand \& Marshall (1985) and Chen \& Zhou (1999). Only a few studies have reported on fingerprinting and genetic diversity of radish varieties with molecular markers Pradhan et al. (2004) and Muminovic et al. (2005) and Rabbani et al. (1998) and Kong et al. (2005) and Liu et al. (2007). Currently, there are several different molecular marker systems available for variety identification. Molecular markers may exhibit sufficient polymorphism and provide potential tools for effective and efficient germplasm evaluation and genetic mapping of important traits in many crops (Hu and Quiros, 1991, Archak et al., 2003 and Liu et al., 2003, 2004). The RAPD marker, being technically simple and fast; (Williams et al., 1990) has been successfully applied in variety identification and genetic diversity analysis in radish (Rabbani et al., 1998, Pradhan et al., 2004 and Huh \& Ohnishi, 2002).

The aim of this experiment was to study the differences in growth and root characters, fixed oil production as well as its chemical composition and molecular genetic identification between some introduced and local radish varieties under Egyptian conditions to be used in breeding programs.

\section{Material and Methods}

This study was conducted during two seasons, of 2010/2011 and 2011/2012. Two field experiments, in this investigation, were conducted at Vegetables Research Farm in Kaha, Governorate, Horticulture Research Institute, Agriculture Research Centre. 


\section{First experiment}

Seeds of local radish varieties (Inbred line selected, Ballady, Round-Red) and Chinese radish varieties (Lingyu, Lingcui, Hongxiu, Fongguang and Guoguang) were sown in a well prepared soil on October $15^{\text {th }}$ in the two seasons obtaining root and vegetative yield after 45 days from planting. The plot area was $3 \times 3 \mathrm{~m}$ with 6 rows $60 \mathrm{~cm}$ apart and $25 \mathrm{~cm}$ between hills.

\section{Second experiment}

The root of all varieties were planted on $15^{\text {th }}$ December in rows $(80 \mathrm{~cm}$ between rows and $20 \mathrm{~cm}$ between plants) to obtain seed yield on 15 May.

The usual cultural procedures of radish growing including fertilization which was done using $350 \mathrm{~kg}$ ammonium -sulphate, $200 \mathrm{~kg}$ calcium super phosphate and $200 \mathrm{~kg}$ potassium sulphate /fed. were added in three equal doses after 2, 3 and 4 months from planting. Other agricultural practices, i.e. irrigation, disease and pest control were followed according to the recommendation of the Egyptian Ministry of Agriculture.

\section{Data recorded}

First experiment

The following data were recorded in each season after 45 days from seed planting:

Vegetative growth

- $\quad$ Plant height $(\mathrm{cm})$

- $\quad$ Leaves weight (g)

- $\quad$ Number of leaves/plant

- $\quad$ Plant weight (g)

- $\quad$ Root length $(\mathrm{cm})$

- $\quad$ Root diameter $(\mathrm{cm})$

- $\quad$ Root weight (g)

Second experiment

Seed yield and fixed oil analysis

The following data were recorded in both seasons after 150 days from root planting.

- $\quad$ Seed yield /plant $(\mathrm{g})$

- $\quad$ Fixed oil (\%)

- $\quad$ Fixed oil yield $(\mathrm{ml}) /$ plant

Determination of fixed oil percentage, oil yield per plant and its components

Fixed oil extracted from radish seeds using Soxhlet apparatus according to the method described in the British Pharmacopoeia (1963) and G.L.C. analysis was also recorded by G.C./ Mass in the second season 2011/2012. 
Molecular genetic identification

Genetic identification of radish varieties was performed by Random amplified polymorphic DNA (RAPD) technique using 5 primers Table 1.

PCR analysis

Genomic DNA was isolated from the leaves of plants under investigation using the CTAB method, according to Rogers and Bendich (1985). PCR reactions were performed in a total volume of $20 \mu \mathrm{l}$ containing $10 \mathrm{ng}$ DNA, 200 $\mu \mathrm{M}$ dNTPs, $1 \mu \mathrm{M}$ primers (operon Technology, Inc., Alameda, CA, USA), 0.5 units of Red Hot Taq polymerase (AB gene House, UK) and 10-X Taq polymerase buffer (AB gene House, UK).

For DNA amplification, Biometra thermal cycler (2720) programmed as follow: (cycle 1: $94^{\circ} \mathrm{C}$ for 2 minutes, cycle $2: 94^{\circ} \mathrm{C}$ for 45 seconds, cycle $3: 35^{\circ} \mathrm{C}$ for 45 seconds, cycle $4: 72^{\circ} \mathrm{C}$ for 1 minute, cycle 5: go to cycle 2 with 29 times, cycle 6 : $72^{\circ} \mathrm{C}$ for 8 minutes, and store at $4^{\circ} \mathrm{C}$. PCR amplification was performed using five random 10 mer arbitrary primers synthesized by Operon biotechnologies, (Inc. Germany).

TABLE A. primers sequences:

\begin{tabular}{|c|c|}
\hline \multicolumn{1}{|c|}{ Primer names } & Sequences \\
\hline OPE- B-05 & 5`TGCGCCCTTC3 \\
OPE- D-05 & 5'TGAGCGGACA3 \\
OPE- K-12 & 5`TGGCCCTCAC3 \\
OPE- N-13 & 5 AGCGTCACTC3 \\
OPE- P-15 & 5'GGAAGCCAAC3 \\
\hline
\end{tabular}

Data analysis

The similarity matrices were done using Gel works ID advanced software UVP-England Program. The relationships among genotypes as revealed by dendrograms were done using SPSS windows (Version 10) program. DICE computer package was used to calculate the pairwise difference matrix and plot the phenol gram among varieties (Yang and Quiros, 1993).

The obtained data were statistically analyzed using the complete randomized blocks design (Simple experiment) with three replicates; separation between means was performed by the L.S.D at $5 \%$ level by Snedecor and Cochran (1982).

\section{Results and Discussion}

Vegetative growth

The data presented in Table 1 indicated that, significant differences in plant length, leaves number, leaves weight and plant weight between the introduced and local varieties were found. 
The data, generally, show that, plant length ranged $(43.6-115.7 \mathrm{~cm})$ in the first season and $(55.7-137.8 \mathrm{~cm})$ in the second season, the lowest plant length were always recorded in the local varieties Ballady, while the highest plant length was recorded in introduced Lingcui variety in both seasons, respectively.

Regarding the leaves number, it was clear that values of leaves number in varieties recorded significant differences in the two seasons. The greatest leaves numbers were recorded in Lingcui variety (13.7 \& 17.0), while the least leaves number was recorded in Ballady variety $(5.3 \& 6.0)$ in the two seasons, respectively.

TABLE 1. Characteristics of the vegetative growth per plant of some introduced and local radish varieties under Egyptian conditions during 2010/2011 and 2011/2012 seasons.

\begin{tabular}{|c|c|c|c|c|}
\hline Characters & $\begin{array}{c}\text { Plant } \\
\text { length } \\
(\mathrm{cm})\end{array}$ & $\begin{array}{l}\text { Leaves } \\
\text { number }\end{array}$ & $\begin{array}{l}\text { Leaves } \\
\text { weight } \\
\text { (g) }\end{array}$ & $\begin{array}{c}\text { Plant } \\
\text { weight } \\
\text { (g) }\end{array}$ \\
\hline Genotype & \multicolumn{4}{|c|}{ First season $(2010 / 2011)$} \\
\hline Lingcui & $115.7 \mathrm{~A}$ & $13.7 \mathrm{~A}$ & $217.1 \mathrm{~A}$ & $424.9 \mathrm{~B}$ \\
\hline Fongguang & $90.5 \mathrm{~B}$ & $11.0 \mathrm{~B}$ & $120.8 \mathrm{C}$ & $589.6 \mathrm{~A}$ \\
\hline Lingyu & $72.7 \quad \mathrm{C}$ & $10.3 \mathrm{~B}$ & $196.2 \mathrm{~B}$ & $583.5 \mathrm{~A}$ \\
\hline Guoguang & $104.7 \mathrm{AB}$ & $10.0 \mathrm{~B}$ & $124.7 \mathrm{C}$ & $339.6 \mathrm{C}$ \\
\hline Hongxiu & $54.2 \mathrm{DE}$ & $9.3 \mathrm{~B}$ & $132.2 \mathrm{C}$ & $252.5 \mathrm{D}$ \\
\hline Inbred line selected & $55.1 \quad \mathrm{DE}$ & $5.3 \mathrm{C}$ & $32.0 \quad \mathrm{D}$ & $39.4 \quad E$ \\
\hline Ballady & $43.6 \quad \mathrm{E}$ & $\begin{array}{ll}5.3 & \mathrm{C} \\
\end{array}$ & $11.9 \mathrm{D}$ & 27.3 \\
\hline \multirow[t]{2}{*}{ Round-Red } & $61.6 \quad \mathrm{CD}$ & 5.7 & $23.4 \quad \mathrm{D}$ & 70.5 \\
\hline & \multicolumn{4}{|c|}{ Second season $(2011 / 2012)$} \\
\hline Lingcui & $137.8 \mathrm{~A}$ & $17.0 \mathrm{~A}$ & $235.0 \mathrm{~A}$ & $657.7 \quad \mathrm{BC}$ \\
\hline Fongguang & $124.9 \mathrm{~A}$ & $15.0 \mathrm{AB}$ & $187.3 \mathrm{~B}$ & $895.0 \mathrm{~A}$ \\
\hline Lingyu & $90.0 \mathrm{~B}$ & $12.7 \mathrm{BC}$ & $220.7 \mathrm{~A}$ & $762.7 \quad \mathrm{~B}$ \\
\hline Guoguang & $134.4 \mathrm{~A}$ & $13.0 \mathrm{BC}$ & $161.1 \mathrm{BC}$ & $334.1 \quad \mathrm{D}$ \\
\hline Hongxiu & $59.1 \quad \mathrm{DE}$ & $10.7 \mathrm{C}$ & $139.3 \mathrm{C}$ & $605.3 \mathrm{C}$ \\
\hline Inbred line selected & $74.8 \mathrm{C}$ & $6.3 \quad \mathrm{D}$ & $51.2 \quad \mathrm{DE}$ & $95.8 \quad \mathrm{EF}$ \\
\hline Ballady & $55.7 \quad \mathrm{E}$ & 6.0 & $24.5 \quad \mathrm{E}$ & $43.2 \quad \mathrm{~F}$ \\
\hline Round-Red & $71.5 \quad \mathrm{CD}$ & 8.0 & 62.3 & $177.7 \quad \mathrm{E}$ \\
\hline
\end{tabular}

The leaves weight $(\mathrm{g})$ in Table 1 gave the same trend in both seasons, the greatest leaves weight (g) were recorded in Lingcui variety (217.1\& 235.0), while the least leaves weight recorded in Ballady variety $(11.9 \& 24.5)$ in the two seasons, respectively.

Data in Table 1 revealed that, the different varieties of radish showed a significant differences in plant weight $(\mathrm{g})$ in the two seasons, the results found that, the Fongguang variety produced the highest value (589.6 and $895.0 \mathrm{~g} / \mathrm{plant}$ ), while the lowest value (27.3 and $43.2 \mathrm{~g} /$ plant ) was recorded in Ballady variety in both season, respectively.

Egypt. J. Hort. Vol. 41, No.1 (2014) 


\section{Root parameters}

Data in Table 2 indicated that, root parameters [root length $(\mathrm{cm})$, root diameter $(\mathrm{cm})$ and root weight $(\mathrm{g})$ ] showed significant differences between the tested radish varieties in both seasons.

The highest recorded values of root length were $(20.53$ and $28.53 \mathrm{~cm})$ in Fongguang variety while, the lowest values were $(5.23$ and $6.27 \mathrm{~cm}$ ) in Round red variety in the two seasons, respectively.

Regarding the root diameter $(\mathrm{cm})$ it was clear from the data in Table 2 that the values of root diameter of all varieties recorded a significant differences in the two seasons. The value of root diameter ranged between $(5.23$ and $1.47 \mathrm{~cm})$ in the first season and $(7.07$ and $2.27 \mathrm{~cm})$ in the second season. The lingyu variety recorded the highest value of root diameter while, the Ballady variety recorded the lowest value in both seasons.

TABLE 2. Characteristics of the root parameters per plant of some introduced and local radish varieties under Egyptian conditions during 2010/2011 and 2011/2012 seasons.

\begin{tabular}{|c|c|c|c|}
\hline Characters & $\begin{array}{l}\text { Root length } \\
(\mathrm{cm})\end{array}$ & $\begin{array}{l}\text { Root diameter } \\
(\mathbf{c m})\end{array}$ & $\begin{array}{c}\text { Root weight } \\
\text { (g) }\end{array}$ \\
\hline & \multicolumn{3}{|c|}{ First season $(2010 / 2011)$} \\
\hline Lingcui & $18.10 \mathrm{~A}$ & $4.73 \mathrm{AB}$ & $366.4 \quad \mathrm{~B}$ \\
\hline Fongguang & $20.53 \mathrm{~A}$ & $4.30 \mathrm{BC}$ & $468.8 \mathrm{~A}$ \\
\hline Lingyu & $18.00 \mathrm{~A}$ & $5.23 \mathrm{~A}$ & $228.7 \quad \mathrm{C}$ \\
\hline Guoguang & $13.27 \mathrm{~B}$ & $4.00 \mathrm{C}$ & $214.9 \mathrm{C}$ \\
\hline Hongxiu & $12.83 \mathrm{~B}$ & $4.37 \mathrm{BC}$ & $120.3 \quad \mathrm{D}$ \\
\hline Inbred line selected & $7.47 \mathrm{C}$ & $1.77 \quad \mathrm{D}$ & $\begin{array}{ll}17.4 & \mathrm{E}\end{array}$ \\
\hline Ballady & $7.00 \mathrm{C}$ & $\begin{array}{ll}1.47 & \mathrm{D}\end{array}$ & 15.3 \\
\hline \multirow[t]{2}{*}{ Round-Red } & $5.23 \mathrm{C}$ & $4.07 \mathrm{BC}$ & $47.1 \quad \mathrm{DE}$ \\
\hline & \multicolumn{3}{|c|}{ Second season $(2011 / 2012)$} \\
\hline Lingcui & $19.73 \mathrm{C}$ & $5.63 \mathrm{~B}$ & $422.7 \quad \mathrm{C}$ \\
\hline Fongguang & $28.53 \mathrm{~A}$ & $5.53 \quad \mathrm{~B}$ & $674.3 \mathrm{~A}$ \\
\hline Lingyu & $23.33 \mathrm{~B}$ & $7.07 \mathrm{~A}$ & $575.3 \mathrm{AB}$ \\
\hline Guoguang & $18.67 \mathrm{C}$ & $4.20 \mathrm{C}$ & $173.0 \quad \mathrm{D}$ \\
\hline Hongxiu & $13.80 \quad \mathrm{D}$ & $6.10 \mathrm{AB}$ & $466.0 \mathrm{BC}$ \\
\hline Inbred line selected & $13.17 \quad \mathrm{D}$ & $2.70 \quad \mathrm{D}$ & $44.5 \quad \mathrm{E}$ \\
\hline Ballady & $9.80 \quad \mathrm{E}$ & $2.27 \quad \mathrm{D}$ & $18.7 \quad \mathrm{E}$ \\
\hline Round-Red & 6.27 & $5.90 \mathrm{~B}$ & $112.8 \quad \mathrm{DE}$ \\
\hline
\end{tabular}

Data in Table 2 showed significant differences between radish varieties in root weight $(\mathrm{g})$. The highest values (468.8 and 674.3) were obtained from Fongguang variety, while the lowest (15.3 and 18.7) was found in case of the Ballady variety in the two seasons, respectively.

Egypt. J. Hort. Vol. 41, No.1 (2014) 
Seed yield/plant ( $\mathrm{g}$ ), fixed oil percentage, oil yield/plant $(\mathrm{ml})$ and fixed oil composition Seed yield /plant $(g)$

Data presented in Table 3 showed significant differences in seed yield plant $(\mathrm{g})$, fixed oil percentage and oil yield/ plant $(\mathrm{ml})$ between the local and introduced varieties in both season.

The value of seed yield /plant (g) ranged between (21.67 and 37.01) in the first season and (20.40 and 34.53) in the second season. The Fongguang variety recorded the highest values of seed yield /plant followed by Lingyu variety while, the Ballady variety recorded the lowest values in both seasons.

Regarding the fixed oil percentage, the data in Table 3 showed significant differences between the tested radish varieties. The highest fixed oil percentage (46.0 and 47.93) was obtained from Guoguang variety, while the lowest percentage (35.00 and 34.33) was found in case of the Lingcui variety in the two seasons, respectively.

Concerning, the oil yield /plant (ml) it was clear from the obtained data Table 3 that, values of fixed oil yield $(\mathrm{ml}) /$ plant in varieties recorded a significant differences in the two seasons. The greatest oil yield ( $\mathrm{ml}$ )/ plant were recorded in Fongguang, Lingyu and Guoguang varieties (13.30, 13.30 and 12.67) in the first season, respectively, meanwhile in the second season Guoguang, Fongguang and Lingyu varieties yielded $(14.07,13.10$ and 11.90), respectively. While the least oil yield (ml)/ plant recorded in Round-Red variety (8.27 and 7.40) in the two seasons, respectively.

TABLE 3. Seed yield / plant (gm), fixed oil percentage and fixed oil yield / plant (ml) of some introduced and local radish varieties under Egyptian conditions during 2010/2011 and 2011/2012 seasons.

\begin{tabular}{|l|rl|rl|r|r|}
\hline \multirow{2}{*}{ Genotype } & Seed yield / plant (g) & \multicolumn{6}{|c|}{$\begin{array}{c}\text { Fixed oil } \\
(\%)\end{array}$} & $\begin{array}{c}\text { Fixed oil yield } \\
\text { / plant (ml) }\end{array}$ \\
\cline { 2 - 8 } & \multicolumn{6}{|c|}{ First season (2010/2011) } \\
\hline Lingyu & 37.00 & $\mathrm{~A}$ & 35.67 & $\mathrm{~B}$ & 13.30 & $\mathrm{~A}$ \\
\hline Lingcui & 24.47 & $\mathrm{~B}$ & 35.00 & $\mathrm{~B}$ & 8.53 & $\mathrm{C}$ \\
\hline Hongxiu & 24.83 & $\mathrm{~B}$ & 43.00 & $\mathrm{~A}$ & 10.63 & $\mathrm{~A}-\mathrm{C}$ \\
\hline Fongguang & 37.01 & $\mathrm{~A}$ & 35.67 & $\mathrm{~B}$ & 13.30 & $\mathrm{~A}$ \\
\hline Guoguang & 27.57 & $\mathrm{~B}$ & 46.00 & $\mathrm{~A}$ & 12.67 & $\mathrm{AB}$ \\
\hline Inbred line selected & 24.20 & $\mathrm{~B}$ & 36.33 & $\mathrm{~B}$ & 8.83 & $\mathrm{C}$ \\
\hline Ballady & 21.67 & $\mathrm{~B}$ & 46.00 & $\mathrm{~A}$ & 9.97 & $\mathrm{BC}$ \\
\hline Round-Red & 22.10 & $\mathrm{~B}$ & 37.00 & $\mathrm{~B}$ & 8.27 & $\mathrm{C}$ \\
\hline & \multicolumn{5}{|c|}{ Second season $(\mathbf{2 0 1 1} / \mathbf{2 0 1 2})$} & \\
\hline Lingyu & 32.63 & $\mathrm{AB}$ & 36.60 & $\mathrm{D}$ & 11.90 & $\mathrm{~B}$ \\
\hline Lingcui & 23.70 & $\mathrm{C}$ & 34.33 & $\mathrm{E}$ & 8.17 & $\mathrm{DE}$ \\
\hline Hongxiu & 22.50 & $\mathrm{C}$ & 42.00 & $\mathrm{~B}$ & 9.43 & $\mathrm{CD}$ \\
\hline Fongguang & 34.53 & $\mathrm{~A}$ & 37.93 & $\mathrm{CD}$ & 13.10 & $\mathrm{AB}$ \\
\hline Guoguang & 29.33 & $\mathrm{~B}$ & 47.93 & $\mathrm{~A}$ & 14.07 & $\mathrm{~A}$ \\
\hline Inbred line selected & 22.00 & $\mathrm{C}$ & 39.50 & $\mathrm{C}$ & 8.73 & $\mathrm{C}-\mathrm{E}$ \\
\hline Ballady & 20.77 & $\mathrm{C}$ & 46.50 & $\mathrm{~A}$ & 9.70 & $\mathrm{C}$ \\
\hline Round-Red & 20.40 & $\mathrm{C}$ & 36.17 & $\mathrm{DE}$ & 7.40 & $\mathrm{E}$ \\
\hline
\end{tabular}

Egypt. J. Hort. Vol. 41, No.1 (2014) 


\section{Fixed oil composition}

The data of G.L.C. analysis of fixed oil of some local and introduced radish varieties, in the second season was presented in Table 4.

The chromatograms of radish seeds fixed oil constituents indicated the relative percentages of 12 identified components of fatty acids. Those fatty acides are; palmitic acid, followed by palmitoleic acid, heptadecanoic acid, ginkgolic acid, stearic acid, oleic acid, linoleic acid, $\alpha$ - linoleic acid, arachidic acid, eicosenoic acid, behenic acid and erucic acid.

\section{Palmitic acid (C16:0)}

Data recorded for radish seeds oil constituents in Table 4, revealed that, palmitic acid was generally affected by different species, the highest value was recorded $(23 \%)$ in Inbred line selected variety while, the values in the other varieties ranged between $(5.3-7.6 \%)$ the lowest value $(5.3 \%)$ was obtained in Chinese radish variety (Lingcui) .

\section{Palmitoleic acid (C16:1)}

Data in Table 4 indicated that, palmitoleic acid ratio varied from variety to another the ratio ranged between $(0.18 \%)$ and $(0.29 \%)$ in Chinese radish variety (Lingyu), while this fatty acid content was disappear in Inbred line selected radish variety.

\section{Heptadecanoic acid (C17:0)}

The obtained data in Table 4 showed a little ratio of fatty acid (heptadecanoic acid) in all varieties under evaluation. The ratio ranged between $(0.02-0.22 \%)$ in all varieties under evaluation. The highest percent recorded in Inbred line selected variety $(0.22 \%)$ while, the lowest ratio $(0.02 \%)$ recorded in Round red variety.

\section{Ginkgolic acid (C17:1)}

The obtained data in Table 4 indicated a little ratio of the fatty acid (ginkgolic) in all varieties under evaluation. The ratio ranged between $(0.02-$ $0.16 \%)$. The highest percentage was recorded in Round red variety $(0.16 \%)$ while, the lowest ratio $(0.02 \%)$ was recorded in Lingcui variety but, this fatty acid was disappear in Inbred line selected radish variety.

\section{Stearic acid (C18:0)}

Data in Table 4 showed that, stearic acid percentage in the varieties under evaluation was ranged between $(1.6 \%)$ in Ballady and Round red varieties to $(2.5$ $\%$ ) in Chinese radish variety (Guoguang), while Inbred line selected variety recorded highest ratio $(7.9 \%)$.

\section{Oleic acid (C18:1)}

Oleic is a fatty acid that exists in large quantities in the radish fixed oil seeds on all varieties under evaluation. The ratios are ranging between $(15.0-31.3 \%)$. The highest percent was recorded in Lingyu variety $(31.3 \%)$ while, the lowest ratio $(15.0 \%)$ was recorded in Inbred line selected variety. 
TABLE 4. Main composition of fixed oil (\%) of some introduced and local radish varieties under Egyptian conditions during second season 2011/2012.

\begin{tabular}{|c|c|c|c|c|c|c|c|c|}
\hline \multirow{2}{*}{$\begin{array}{c}\text { Main } \\
\text { composition } \\
\text { of fatty acid } \\
(\%)\end{array}$} & \multicolumn{8}{|c|}{ Genotype } \\
\hline & Lingyu & Lingcui & Hongxiu & Fongguang & Guoguang & $\begin{array}{c}\text { Inbred line } \\
\text { selected }\end{array}$ & Ballady & $\begin{array}{c}\text { Round- } \\
\text { Red }\end{array}$ \\
\hline $\begin{array}{l}\text { C16:0 } \\
\text { Palmitic acid }\end{array}$ & 7.6 & 5.3 & 5.7 & 5.6 & 6.8 & 23.0 & 5.7 & 5.8 \\
\hline $\begin{array}{l}\text { C16:1 } \\
\text { Palmitoleic acid }\end{array}$ & 0.29 & 0.18 & 0.18 & 0.21 & 0.22 & ---- & 0.22 & 0.21 \\
\hline $\begin{array}{l}\text { C17:0 } \\
\text { Heptadecanoic } \\
\text { acid }\end{array}$ & 0.05 & 0.09 & 0.03 & 0.03 & 0.07 & 0.22 & 0.2 & 0.02 \\
\hline $\begin{array}{l}\text { C17:1 } \\
\text { Ginkgolic acid }\end{array}$ & 0.04 & 0.02 & 0.07 & 0.06 & 0.05 & ---- & 0.08 & 0.16 \\
\hline $\begin{array}{l}\text { C18:0 } \\
\text { Stearic acid }\end{array}$ & 2.3 & 2.3 & 2.0 & 1.9 & 2.5 & 7.9 & 1.6 & 1.6 \\
\hline $\begin{array}{l}\text { C18:1 } \\
\text { Oleic acid }\end{array}$ & 31.3 & 20.6 & 28.6 & 25.7 & 27.5 & 15.0 & 24.4 & 23.9 \\
\hline $\begin{array}{l}\text { C18:2 } \\
\text { Linoleic acid }\end{array}$ & 3.2 & 4.75 & 13.0 & 10.4 & 3.8 & 0.82 & 12.1 & 11.9 \\
\hline $\begin{array}{l}\text { C18:3 }{ }^{\alpha-} \\
\text { Linoleic acid }\end{array}$ & 0.5 & 2.04 & 8.8 & 5.3 & 0.95 & 0.20 & 8.9 & 8.1 \\
\hline $\begin{array}{l}\text { C20:0 } \\
\text { Arachidic acid }\end{array}$ & 1.3 & 1.1 & 1.1 & 1.3 & 1.6 & 2.4 & 1.0 & 1.4 \\
\hline $\begin{array}{l}\text { C20:1 } \\
\text { Eicosenoic acid }\end{array}$ & 11.6 & 12.1 & 6.4 & 10.9 & 12.5 & 7.9 & 9.6 & 10.2 \\
\hline $\begin{array}{l}\text { C22:0 } \\
\text { Behenic acid }\end{array}$ & 1.0 & 0.96 & 0.73 & 0.34 & 0.13 & 2.5 & 0.57 & 0.45 \\
\hline $\begin{array}{l}\text { C22:1 } \\
\text { Erucic acid }\end{array}$ & 40.7 & 48.8 & 29.1 & 37.8 & 42.7 & 33.9 & 35.2 & 36.0 \\
\hline Total & 99.88 & 98.2 & 95.71 & 99.55 & 98.82 & 93.84 & 99.57 & 99.75 \\
\hline
\end{tabular}

Linoleic acid (C18:2)

Linoleic acidis, the main fatty acid in the seed fixed oil composition of radish. Data in Table 4 showed variation in the ratio of linoleic acid in the radish seed fixed oil between varieties under evaluation. It ranged between $0.82 \%$ in Inbred line selected variety and $13.0 \%$ in Chinese radish variety (Hongxin).

\section{$\alpha$ - Linoleic acid (C18:3)}

Data in Table 4 showed that, $\alpha$ - linoleic acid percentage ranged between (0.2 -8.9 $\%$ ) in the fixed seed oil composition of the tested radish varieties. The highest value recorded $(8.9 \%)$ in Ballady variety and $(8.8 \%)$ in Chinese radish variety (Hongxin) while, the lowest value recorded $(0.2 \%)$ in the Inbred line selected variety.

Arachidic acid (C20:0)

Data in Table 4 demonstrated that, arachidic fatty acid ratio ranged between $(1.0 \%)$ in Ballady variety to $(2.4 \%)$ in Inbred line selected variety.

\section{Eicosenoic acid (C20:1)}

Eicosenoic is a fatty acid that exists in large quantities ratio in the radish fixed oil seeds on all varieties under evaluation. The ratios ranged between $(6.4-$ 
$12.5 \%)$. The highest percent was recorded $(12.5 \%)$ in Guoguang variety while, the lowest ratio $(6.4 \%)$ was recorded in Hongxin variety.

Behenic acid (C22:0)

Data in Table 4 showed that, Behenic acid percentage ranged between $(0.13$ $2.5 \%)$ in the seed fixed oil composition of radish varieties. The highest value recorded $(2.5 \%)$ was in Inbred line selected variety while, the lowest value recorded $(0.13 \%)$ was in the Guoguang variety.

Erucic acid (C22:1)

Erucic acid which is the most common fatty acid in the seed fixed oil of the family Brassicaceae. Fixed oil quality is measured by Erucic acid ratio in the oil composition, a good radish fixed oil is the one which contains little ratio of Erucic acid. Data in Table 4 showed the ratio of Erucic acid in the fixed oil of all varieties. It ranged between $(29.1 \%)$ in Hongxiu variety to (48.8\%) in Lingcui variety.

\section{Molecular genetic identification}

Randomly amplified polymorphic DNA (RAPD) markers

The five 10-mer arbitrary primers succeeded in amplifying DNA fragments for the eight genotypes of radish varieties is illustrated in Table 5 and Fig. 1. Polymorphism levels were not much differ from one primer to another. OPP15primer exhibited low level of polymorphism (54.5\%). On the other hand, OPD05, OP-N13. and OP-B05 primers exhibited moderate levels of polymorphism $(60 \%, 63.6 \%$ and $64.3 \%)$, respectively. While OP-K12 primer exhibited high level of polymorphism (72.2\%). The number of total amplified fragments (TAF), polymorphic fragments (PF), monomorphic fragments (MF) and specific markers (SM) for each sample using the five primers are shown in Table 5. OP-B05 primer produced fourteen fragments with molecular size ranging from 127 to 1564 bp (Fig. 1). Nin fragments were polymorphic $(64.3 \%)$ and two of them were varieties - specific markers at (334) bp for Fongguang and (434) bp for Round-Red, while the other five fragments were present in all genotypes which are considered as common fragments.

TABLE 5. Species-specific RAPD markers for Radish varieties genotypes.

\begin{tabular}{|c|c|c|c|c|c|c|}
\hline $\begin{array}{l}\text { Primers } \\
\text { code }\end{array}$ & $\begin{array}{l}\text { Range of } \\
\text { M.S. }\end{array}$ & TAF & MF & PF & SM & $\begin{array}{c}\text { Polymorphism } \\
(\%)\end{array}$ \\
\hline OP-B05 & $127-1564$ & 14 & 5 & 9 & 2 (334)-(434) bp & 64.3 \\
\hline OP-D05 & $214-1762$ & 10 & 4 & 6 & 1 (1304) bp & 60 \\
\hline OP-K12 & $144-1832$ & 18 & 5 & 13 & $\begin{array}{c}5 \\
(1130,847)- \\
(534,144)-(561) b p\end{array}$ & 72.2 \\
\hline OP-N13 & $500-3108$ & 11 & 4 & 7 & - & 63.6 \\
\hline OP-P15 & $175-1495$ & 11 & 5 & 6 & $2(1459,557) b p$ & 54.5 \\
\hline $\begin{array}{l}\text { Total RAPD } \\
\text { primers }\end{array}$ & & 64 & 23 & 41 & 10 & \\
\hline
\end{tabular}

Fragments, SM= Specific Markers. 


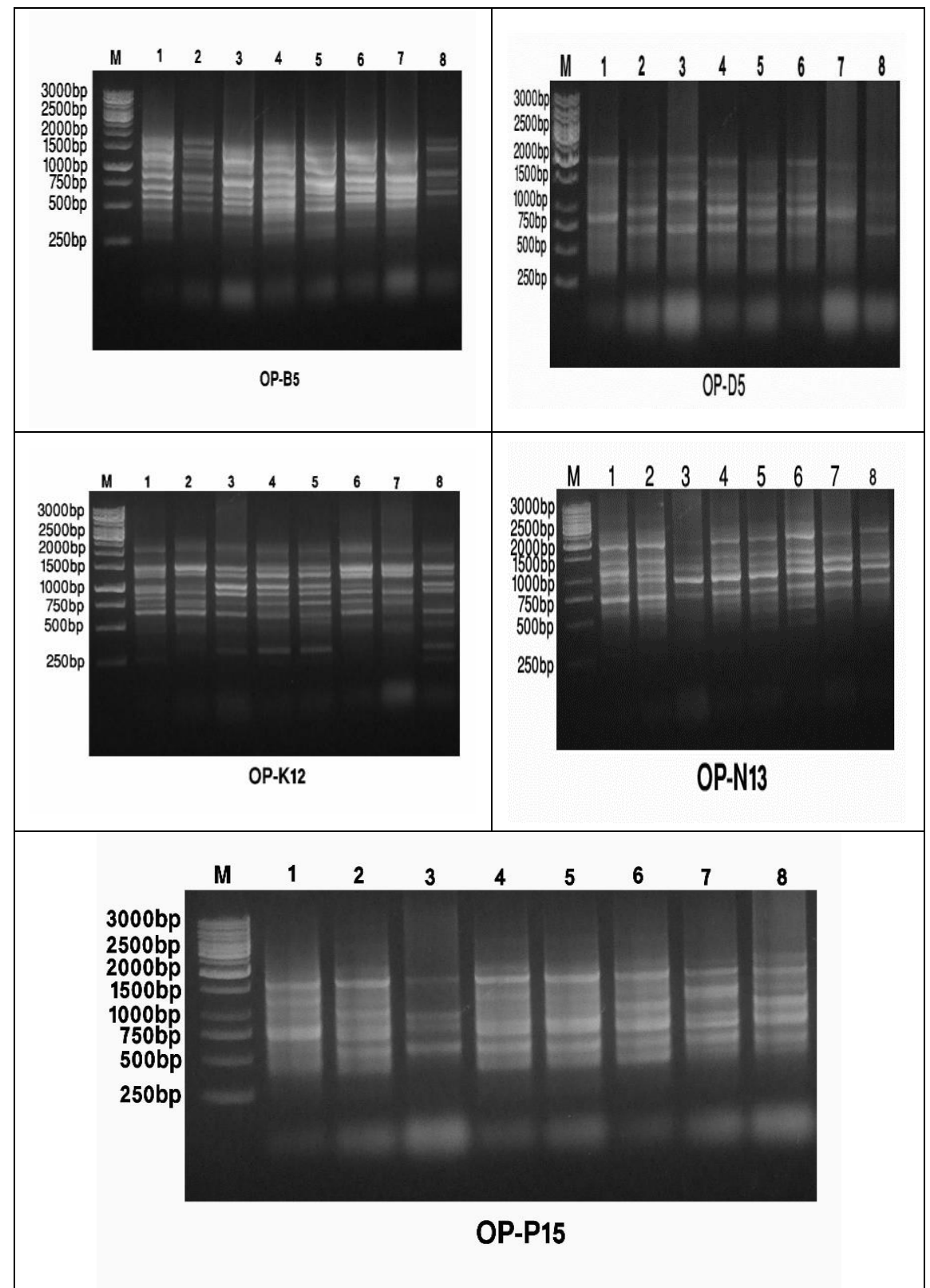

Fig. 1. RAPD-PCR analysis of different Radish varieties cultivated under Egyptian condition.
1-Lingyu
2-Lingcui
3-Hongxiu
4-Fongguang
5-Guoguang
6-Ballady
7- Round-Red
8-Inbred line selected

OP- D05 primer resulted in ten DNA fragments with molecular size ranging from 214 to $1762 \mathrm{bp}$, six fragments were polymorphic $(60 \%)$ in which one of Egypt. J. Hort. Vol. 41, No.1 (2014) 
them (1304) bp was varieties - specific marker for variety Lingyu and the other four fragments were present in all genotypes which are considered as common fragments. For OP- K12 primer resulted in eighteen DNA fragments with molecular size ranging from 144 to $1832 \mathrm{bp}$, thirteen fragments were polymorphic $(72.2 \%)$, and five of them were varieties- specific marker at $(1130,847)$ bp for Lingyu, $(534,144)$ bp for Hongxiu and (561) bp for Guoguang. The other five fragments were presented in all genotypes which are considered as common fragments. Concerning OP- N13 primer resulted in eleven DNA fragments with molecular size ranging from 500 to $3108 \mathrm{bp}$, in which seven fragments were polymorphic $(63.6 \%)$ and the other four fragments were present in all genotypes which are considered as common fragments. OP-P15 primer resulted in eleven DNA fragments with molecular size ranging from 175 to $1495 \mathrm{bp}$, six fragments were polymorphic $(54.5 \%)$ in which two of them were varieties - specific markers at $(1459,557)$ bp for Lingcui, while the other five fragments were presented in all genotypes which are considered as common fragments.

\section{Genetic similarity and cluster analysis based on RAPD markers}

The RAPD data were used to estimate the genetic similarity values among the eight genotypes of radish varieties by using UPGMA computer analysis as in Table 6 and Fig. 2. The genetic similarity derived from the data of RAPD marker analysis varied from (0.11) between Lingyu and Stander and also between Lingcui and both of Hongxiu and Round-Red to (1.0) between Guoguang and Fongguang genotypes as well as between Guoguang and Ballady genotypes. While there was no similarity value was noticed between Lingyu and Hongxiu genotypes as well as between Lingyu and Round-Red genotypes. A dendrogram for the genetic relationship among the eight genotypes of radish varieties genotypes is exhibited in Fig. 2, which separated them into two major groups. The first group included Lingyu and Lingcui genotype, while the second group included four subgroups: the first subgroup involved Hongxiu only and second subgroups involved only Stander genotype, while the third subgroup contained Fongguang, Guoguang and Ballady genotypes and the fourth subgroup included Round-Red genotypes only.
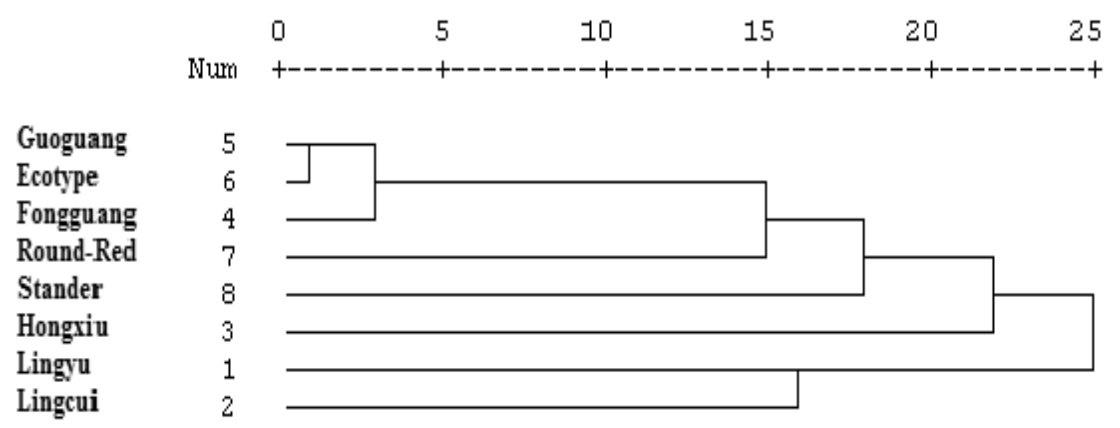

Fig. 2. A dendrogram illustrates the genetic distance for radish varieties genotypes based on RAPD data. 
TABLE 6. Similarity value (Pair wise comparison) of radish varieties genotypes based on RAPD data.

\begin{tabular}{|l|l|l|l|l|l|l|l|}
\hline & Lingyu & Lingcui & Hongxiu & Fongguang & Guoguang & Ballady & $\begin{array}{l}\text { Round- } \\
\text { Red }\end{array}$ \\
\hline Lingyu & & & & & & & \\
\hline Lingcui & 0.50 & & & & & & \\
\hline Hongxiu & 0.00 & 0.11 & & & & & \\
\hline Fongguang & 0.27 & 0.38 & 044 & & & & \\
\hline Guoguang & 0.22 & 0.22 & 0.38 & 1.00 & & & \\
\hline Ballady & 0.27 & 0.27 & .044 & 0.83 & 1.00 & & \\
\hline Round-Red & 0.00 & 0.11 & 0.16 & 0.55 & 0.50 & 0.55 & \\
\hline Inbred line selected & 0.11 & 0.33 & .016 & 0.44 & 0.38 & 0.55 & 0.38 \\
\hline
\end{tabular}

In this study, data in Table 6 clear that, $64 \%$ of bands generated by RAPD assay were polymorphic, which was lower than the polymorphic proportion of 78.2\% detected by RAPD among Pakistan radish germplasms (Rabbani et al., 1998). However, polymorphism ratio was detected $88.5 \%$ among Australian radish varieties (Pradhan et al., 2004), 85.4\% among late-bolting radish varieties (Liu et al., 2008) and $82 \%$ in wild radish population (Raphanus raphanistrum L.) (Madhou et al., 2005). Also in this study, the RAPD data were integrated to elucidate the genetic relationships among the radish germplasms. Moreover, the results showed diverse genetic differences among these germplasms, which could be exploited for radish genetic improvement. The morphological characters used organized the radish germplasm into established taxonomic grouping, reflecting the role which morphology has played historically in radish classification.

\section{Conclusion}

From previous results it can be concluded that, Fongguang variety overpass the characteristics of root length, root weight, seed yield/plant (g) and fixed oil yield/plant (ml). Meanwhile, Lingyu variety overpass of root diameter, seed yield/plant ( $\mathrm{g}$ ) and fixed oil yield/plant $(\mathrm{ml})$, on the fixed oil constituents the best variety which gave the highest value from palmitic acid constituent was obtained from Inbred line selected variety while, oleic acid from Lingyu variety the lowest value from Erucic acid (29.1 \%) was obtained from Hongxiu variety. This study provides evidence that RAPD polymorphism could be used as efficient tools for the detection of similarities and phylogenetic relationships of the studied genotypes. Results presented here enable us to identify, select and combine some interesting traits in landraces to obtain improved varieties.

\section{References}

Archak, S., Gaikwad, A.B., Gautam, D., Rao, E.V.V.B., Swamy, K.R.M. and Karihaloo, J.L. (2003) DNA fingerprinting of Indian cashew (Anacardium occidentale L.) varieties using RAPD and ISSR techniques. Euphytica, 230, 397-404.

Egypt. J. Hort. Vol. 41, No.1 (2014) 
British Pharmacopoeia (1963) The Pharmaceutical Press 17 Bloomsburg, Square. W.C.I. London.

Chen, H.M. and Zhou, C.J. (1999) A study on genetic relationship among radish varieties by esterase isoenzymes. J. Hunan. Agric. Univ., 25 (3), 191-193.

Ellstrand, N. C. and Marshall, D. L. (1985) The impact of domestication on distribution of allozyme variation within and among varieties of radish, Raphanus sativus L. Theor. Appl. Genet., 69, 393-398.

George, R.A.T. and Evans, D.R. (1981) A classification of winter radish varieties. Euphytica, 30, 483-492.

Huh, M.K. and Ohnishi, O. (2002) Genetic diversity and genetic relationships of East Asian natural populations of wild radish revealed by AFLP. Breeding Sci., 52, 79-88.

Hu, J. and Quiros, C.F. (1991) Identification of broccoli and cauliflower varieties with RAPD markers. Plant Cell Rep., 10, 505-511.

Kobayashi, K.A., Horisaki, S., Niikura and Ohsawa, R. (2006) Interaccession variation in floral morphology in radish (Raphanus sativus L.). Euphytica, 152, 87-97.

Kong, Q. S., Li, X.X. and Xiang, C.P. (2005) Phylogenetic analysis of cultivated radish (Raphanus sativus L.) germplasm with AFLP. Sci. Agric. Sin., 38 (5), 1017-1023.

Liu, G., Liu, L., Gong, Y., Wang, Y., Yu, F., Shen, H. and Gui, W. (2007) Seed genetic purity testing of F1 hybrid cabbage (Brassica oleracea var. capitata) with molecular marker analysis. Seed Sci. Technol., 35, 476-485.

Liu, L., Guo, W., Zhu, X. and Zhang, T. (2003) Inheritance and fine mapping of fertility-restoration for cytoplasmic male sterility in Gossypium hirsutum L. Theor. Appl. Genet., 106, 461-469.

Liu, L. Gong, W.Y.Q. and Huang, H. (2004) Novel molecular marker system - SRAP and TRAP and their application. Hereditas, 26 (5), 777-781.

Liu, L.W., Zhao, L. P., Gong, Y. Q., Wang, M. X., Chen, L. M., Yang, J. L., Wang, Y., Yu, F. M. and Wang, L.Z. (2008) DNA fingerprinting and genetic diversity analysis of late-bolting radish varieties with RAPD, ISSR and SRAP markers. Sci. Horti., 116, 240-247.

Lu, G., Jiashu, C., Xiaolin, Y., Xun, X. and Hang, C. (2008) Mapping QTLs for root morphological traits in Brassica rapa L. based on AFLP and RAPD markers. J. Appl. Genet., 49, 23-31.

Madhou, P., Wells, A., Pang, E. C. K. and Stevenson, T. W. (2005) Genetic variation in populations of Western Australian wild radish. Aust. J. Agr. Res., 56,1079-1087.

Magdoff, F. and Van, Es., H. (2009) Building soils for better crops, sustainable soil management. Sustainable Agriculture Publications, Waldorf, MD. 
Muminovic, J., Merz, A. and Melchinger, A. E. (2005) Genetic structure and diversity among radish varieties as inferred from AFLP and ISSR analyses. J. Am. Soc. Hort. Sci., 130 (1), 79-87.

Pradhan, A., Yan, G. and Plummer, J. A. (2004) Development of DNA fingerprinting keys for the identification of radish varieties. Aust. J. Exp. Agric., 44, 95- 102.

Rabbani, M.A., Murakami, Y., Kuginuki, Y. and Takayanagi, K. (1998) Genetic variation in radish (Raphanus sativus L.) germplasm from Pakistan. Genet. Resour. Crop. Evol., 45, 307-316.

Rogers, S.O. and Bendich, A.J. (1985) Extraction of DNA from milligram amounts of fresh, herbariurp and mummified plant tissues. Plant Mol Bio., 15, 69-76.

Snedecor, G.W. and Y. Cochran, Y. (1982) Statistical Methods, $7^{\text {th }}$ ed. Iowa State Univ. Press, Iowa, U.S.A.

Tsuro, M., Suwabe, K., Kubo, N., Matsumoto, S. and Hirai, M. (2008) Mapping of QTLs controlling root shape and red pigmentation in radish, Raphanus sativus L. Breed. Sci., 58,55-61.

Weil, R. R., White, C. and Lawley, Y. (2006) Forage radish: new multi-purpose cover crop for the Mid-Atlantic. Univ. of Maryland Cooperative Extension Fact Sheet 824, College Park.

Williams, J. G. K. Kubelik, A.R., Livak, K.J., Rafalski, J. A. and Tingey, S. V. (1990) DNA polymorphisms amplified by arbitrary primers are useful as genetic markers. Nucleic Acids Res., 18, 6531-6535.

Yang, X. and Quiros, C. F. (1993) Identification and classification of celery varieties with RAPD markers. Theoritical and Appleid Genetics, 86, 205-212.

(Received 26/2/2014; accepted 25/5/2014) 


\section{تقييم بعض الأصناف المستوردة والمحلية من الفجل تحت الظروف \\ المصرية}

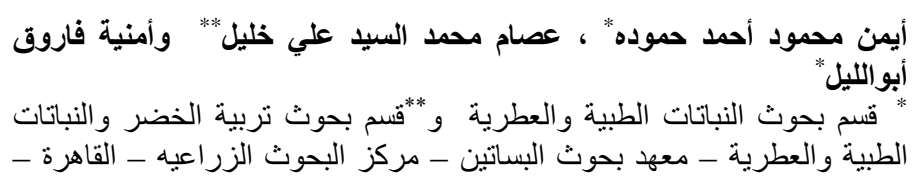

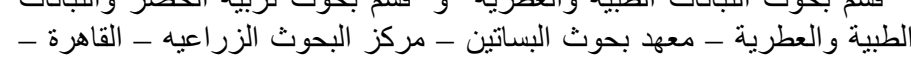

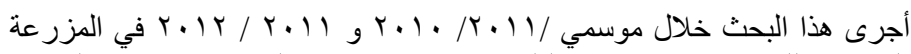

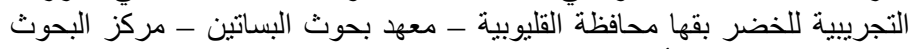

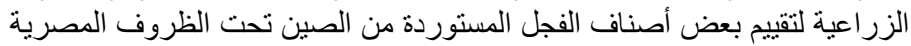

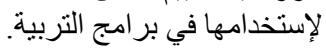

تم زراعة أصناف محلية - Inbred line selected, Ballady, Round

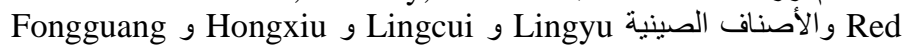
و Guoguang في منتصف شهر أكتوبر في كلا الموسمين.

وقد أظهرت النتائج تفوق صنف الفجل Fongguang في صفات طول ووزن

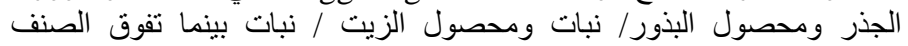

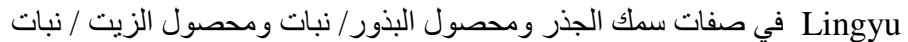

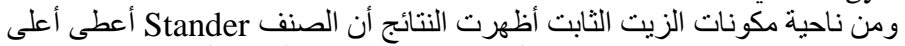

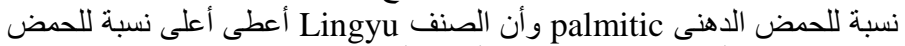

الدهنى oleic و أن الصنف Hongxin أعطى أقل نسبة للحمض الدهنى Erucic

تم دراسة الفروق الوراثية والكيميائية لأصناف الفجل لمعرفة مدى العلاقة

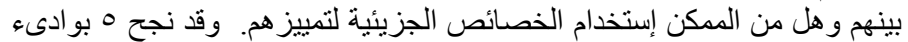

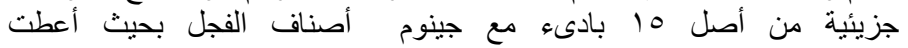

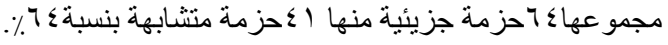

وقد تراوح عدد الحزم الجزيئية ما بين 7 لكل من الباديئين ( OP- D05

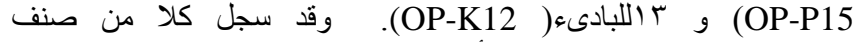

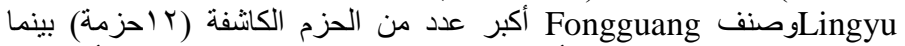

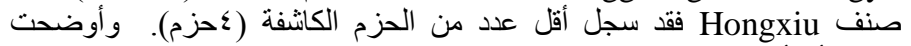
النتائج أن أكبر عدد من الحزم الكاشفة (0 حزمة) كان بإستخدام البادىم)

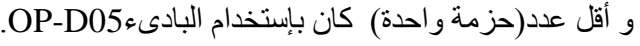

